\title{
Efficacy of Albendazole Against Strongylus sp. and Hematology Changes on Equine in Yogyakarta Special Region
}

\section{Efikasi Albendazole Terhadap Cacing Strongylus sp. dan Gambaran Darah Pada Kuda di Daerah Istimewa Yogyakarta}

\author{
Yuriadi $^{1}$, Ida Tjahajati ${ }^{1 *}$, Guntari Titik Mulyani ${ }^{1}$, Kelviano Muqit ${ }^{2}$, Aidah Rahmanita ${ }^{2}$ \\ ${ }^{1}$ Departement of Veterinary Internal Medicine, Faculty of Veterinary Medicine, \\ Universitas Gadjah Mada, Depok, Sleman, Yogyakarta Special Region (55281) \\ ${ }^{2}$ Faculty of Veterinary Medicine, Universitas Gadjah Mada, Depok, Sleman, \\ Yogyakarta Special region (55281) \\ *Email: yuriadi@ugm.ac.id
}

Recieved: 24 September 2020, accepted: 30 Juni 2021, published: 15 Juli 2021

\begin{abstract}
Abstrak
Infestasi cacing Strongylus sp. pada kuda dapat menimbulkan kerugian pada peternak kuda antara lain kekurusan, anemia, penyakit gastrointestinal dan dapat menimbulkan kematian serta menurunkan populasi kuda di DIY. Albendazole merupakan preparat Benzimidazole yang sering digunakan untuk obat cacing pada ternak ruminansia. Penelitian ini juga bertujuan untuk mengetahui pengaruh Albendazole terhadap gambaran darah sebelum dan sesudah pengobatan. Materi yang digunakan dalam penelitian ini adalah 10 ekor kuda dengan jenis kelamin jantan dan betina berumur lebih dari 3 tahun yang terinfestasi cacing Strongylus sp. dengan angka infestasi 200 EPG feses. Metode yang dilakukan adalah melakukan pemeriksaan terhadap telur cacing Strongylus sp.pada feses kuda dengan angka infestasi sebesar 200 epg feses dengan metode pemeriksaan Mc Master sebelum pengobatan. Setelah pengobatan dengan Albendazole dilakukan pemeriksaan telur cacing sebanyak tiga kali dengan interval waktu tiga hari sekali. Sebelum dan sesudah pengobatan pada hari ke 9 dilakukan pemeriksaan darah rutin. Pemeriksaan telur cacing dan darah rutin dilakukan di Laboratorium Departemen Ilmu Penyakit Dalam Fakultas Kedokteran Hewan Universitas Gadjah Mada. Hasil penelitian menunjukkan jumlah EPG semakin menurun dari hari pemeriksaan ke-0, ke-3, ke-6 dan ke-9. Rata-rata jumlah EPG pada hari ke-0 sebesar 990 telur/gram, dan pemeriksaan pada hari ke-9 menunjukkan jumlah telur sebesar 0 telur/gram. Hasil pemeriksaan hematologi juga menunjukkan tidak adanya perbedaan signifikan kecuali jumlah eusinofil yang cukup tinggi pada hari ke-12 setelah pemberian obat. Kesimpulan dari penelitian ini yaitu Albendazole sebagai obat cacing dapat membunuh cacing Srongylus sp. namun tidak mempengaruhi gambaran darah serta kesehatan kuda.
\end{abstract}

Kata kunci: albendazole; EPG; kuda; status hematologi; Strongylus sp.

\begin{abstract}
The infestation of Strongylus sp. in horses can cause losses to horse breeders, including anorexia, anemia, gastrointestinal diseases and can cause death and decrease the horse population in Yogyakarta Special Region (DIY). Albendazole was a Benzimidazole preparation that is often used to treat worms in ruminants. This study also aims to determine the effect of Albendazole on blood images before and after treatment. The material used in this study were 10 horses with male and female sex, over 3 years old, and infected with Strongylus sp. with an infestation rate of 200 EPG in faeces. Before treatment of drug was carried out, the faeces was examined with Mc Master method. After treatment with Albendazole, the worm eggs were examined three times at intervals of three days. Routine examination of worm eggs and blood was carried out at the Laboratory of the Department of Internal Medicine, Faculty of Veterinary Medicine, Universitas Gadjah Mada. The results showed that the EPG number decreased from the $0^{\text {th }}, 3^{\text {rd }}, 6^{\text {th }}$ and $9^{\text {th }}$ day of examinations. The average number
\end{abstract}


of EPG on the 0th day was 990 eggs/gram, and the examination on the $9^{\text {th }}$ day showed the number of eggs was 0 eggs/gram. The results of the hematology examination also showed no significant difference except for the high number of eosinophils on the 12th day after drug administration. The conclusion from this research is that Albendazole as a worm medicine can kill Srongylus sp. however, it does not affect the horse's hematology and health status.

Keywords: albendazole; EPG; hematology status; horse; Strongylus sp.

\section{Introduction}

Horses are animals that are commonly used as transportation animals, generally as a horse cart or cart. These animals have a significant share in the Yogyakarta area as a popular tourism facility. However, there are many obstacles faced by horse breeders, one of which is the case of gastrointestinal worms (Kristiyani et al., 2019). The main problem in most developing countries is worm infection which causes a decline in the health and performance of the horse. Mild to moderate worm infections do not always show obvious clinical symptoms, while severe adult worm infections can cause digestive disorders and stunted growth in horses (Subekti et al., 2010). Worm infection in adult horses has a lower prevalence, this is because the immune system in adult horses is well developed compared to young horses (Love, 2003).

The decline in horse health itself can be influenced by various factors, including poor environmental conditions, a favorable climate for the development of worms or bacteria, and feed contaminated by infective larvae (Koesdarto et al., 2007). Strongyl worms in horses are generally caused by the nematodes Parascaris equorum and Strongylus sp., A disease caused by these two worms is an important disease for horses and can cause significant losses for horse cart breeders in Yogyakarta (Yuriadi, 2007). According to Apriliawati et al. (2019) and Ratnawati (2014), reported that worm infestations in the gastrointestinal tract in wagon horses in Bogor City were found to have Strongyloid infestations with a prevalence of $70 \%$, Ascarid $46.6 \%$ and Oxyurid as much as 30\%. Meanwhile, Pradana (2012) reported that the sampling in Pohsarang, Kediri showed the prevalence of Strongylus sp. amounted to $34.78 \%$ and Trichonema sp. $8.7 \%$. Siregar (2016) reported that horses in Batu City had a prevalence of Strongylus sp. by $32 \%$, Trichonema sp. $2 \%$ and Parascaris equorum by $2 \%$. Yogyakarta Special Region is a tourist city that is visited by many tourists, both domestic and foreign. One of its attractions is the horse-drawn carriage which is the hallmark of Yogyakarta. Horses are pets as well as transportation animals as carriage towers which have a big share in attracting tourists which also means increased income for the government of the Special Region of Yogyakarta (Yuriadi, 2007).

The use of a broad spectrum anthelmintic (worm medicine) Albendazole is very commonly used in Indonesia. This type of drug that is included in the Benzimidazole group is widely used because of its effectiveness in eliminating gastrointestinal worms (Kristiyani et al., 2019). The use of Albendazole is not common in horses and donkeys, and there is insufficient data available on the toxicity and side effects of the drug in horses and donkeys (Gokbulut et al., 2005). The higher metabolic capacity, the presence of the first pass-effect, and lower absorption of benzimidazole (including Albendazole) in the Equine group compared to ruminants cause the use of albendazole to be rarely used in horses (Imam et al., 2010). The use of albendazole which has been widely used is also feared to cause resistance, Cernea et al. (2007) reported that the widespread use of benzimidazole derivatives in Romania has led to reports of worm resistance. Furthermore, it was explained that the use of Albendazole in comparison with pyrantel resulted in an action that was three times higher than giving Albendazole alone. Research on the efficacy effect of Albendazole against Strongylus sp. and the hematological features of the drug administration have never been carried out in Yogyakarta, so this study aims to determine the effect of Albendazole's killing power against Strongylus sp. on horses in the Yogyakarta area and knowing the effect of albendazole on hematology result before and after treatment. 


\section{Material and Methods}

This study used 10 adult horses from Gamping District, Sleman, 3 horses, 3 horses in Kotagede, Yogyakarta, and 4 Potorono horses, Bantul Regency. The sex of the horse is taken randomly, the mares are taken from those who are not pregnant. The collection was carried out on horses that had a Body Condition Score of 2-3 and were more than 3 years old. Before sampling, a health check was carried out and the selection of horses was prioritized on horses with diarrhea disorders. Accrding to Howell et al. (2008) before giving Albendazole, \pm 10 grams of feces were taken from each horse through the rectum and $10 \mathrm{cc}$ of blood was taken through the jugular vein then placed in a vaccum tube that had been given the anticoagulant Ethylenediaminetetraacetic acid (EDTA) and a small portion of the blood was made smear preparations.

Stool and blood samples were examined at the Laboratory of Internal Medicine, Faculty of Veterinary Medicine, Gadjah Mada University. Examination of feces using the Mc Master method according to Nofyan et al. (2010), the level of infection in animals is divided into three levels based on the number of eggs per gram of feces, namely mild infection if the number of eggs is 1-499 per gram of feces, moderate infection if the number of eggs 5005,000 eggs per gram and severe infection if the number of eggs $>5,000$ eggs per gram of animal feces. Hematological examination based on smear preparations and blood mixed with anticoagulants was performed under an Olympus ${ }^{\circledR}$ microscope at a magnification of $40 \mathrm{x}$. Albendazole anthelminthic administration with a total dose of $5 \mathrm{mg} / \mathrm{kg} \mathrm{BW}$ (Imam et al., 2010) with one administration on day 0. Stool collection for repeated testing with McMaster was carried out on days 3, 6, 9, and 12 .
Meanwhile, the second blood collection after drug administration was carried out on the $12^{\text {th }}$ day. Data from laboratory examination, both feces, and blood tests, were analyzed using a paired T-test and Repeated Measure ANOVA Test and described descriptively.

\section{Results and Discussion}

Examination of worm eggs using fecal media is the main thing in determining the level of worm infestation in an animal's body. The examination used in this research is to use the Mc Master method which is useful for knowing the results quantitatively. Feces examination were carried out repeatedly on day 0 (before treatment) and day 3 , day 6 , and day 9 (after treatment). The results of quantitative examination of worm eggs are shown in Table 1.

The number of worm eggs per gram of feces/egg per gram (EPG) from each of the tests showed different results. Observations on day 0 and day 3 showed significant differences ( $P$ $<0.05$ ), an examination on day 3 to day 6 also showed a significant difference $(\mathrm{P}<0.05)$, while examination on day 6 and the $9^{\text {th }}$ day showed no difference $(\mathrm{P}>0.05)$. Albendazole treatment was carried out on day 1 , based on these results showed a decrease in the amount of EPG from before the treatment $(990.00 \pm 148.69)$ on day 0 and after the occurrence of treatment $(250.00$ $\pm 113.04)$ on day the $3^{\text {rd }}$. The results of the examination showed a reduction in the number of EPG on the $3^{\text {rd }}$ day after giving albendazole by $74.74 \%$, then increased again on the $6^{\text {th }}$ day by $97.47 \%$ and finally reached $100 \%$ on the $9^{\text {th }}$ day post anthelmintic administration. Amin et al. (2008) stated that there was a reduction in the number of worm eggs in donkeys given the 3rd day of Albendazole to $90.44 \%$ of the number of worm eggs compared to the time before being given anthelmintics. Islam et al. (2015) stated

Table 1. Results of quantitative faeces examination with Mc Master methods on days 0, 3, 6, and 9

\begin{tabular}{lccccc}
\hline \multirow{1}{*}{ Parameter } & \multirow{2}{*}{ Sample (n) } & 0 day & \multicolumn{2}{c}{ Post treatment examination } \\
& & $(\mathrm{EPG})$ & $3^{\text {th }}$ day & $6^{\text {th }}$ day & $9^{\text {th }}$ day \\
& & $(\mathrm{EPG})$ & $(\mathrm{EPG})$ & $(\mathrm{EPG})$ \\
\hline $\begin{array}{l}\text { Number of worm eggs } \\
\text { EPG decrease }\end{array}$ & 10 & $990,00 \pm 148,69^{\mathrm{a}}$ & $250,00 \pm 113,04^{\mathrm{b}}$ & $25,00 \pm 26,35^{\mathrm{c}}$ & $0,00 \pm 0,00^{\mathrm{c}}$ \\
\hline
\end{tabular}

a-b-c Valures of different superscript on the same line are significantly different $(\mathrm{P}<0,05)$. 
that in cows given Albendazole on day 0 the average amount of EPG was $810 \pm 33.17$ eggs/ gram on the $7^{\text {th }}$ day post-treatment the number of eggs decreased by $46.91 \%(430 \pm 20.00$ eggs/ gram), then on the $14^{\text {th }}$ day the number of eggs decreased to $72.84 \%$ (220 \pm 9.49 eggs/gram $)$, on the $21^{\text {st }}$ day it decreased again to reach $84.88 \%$ of the number of eggs at the start of the study (126 \pm 9.80 eggs/gram).

Saeed et al. (2008) reported that the use of Farbenda ${ }^{\circledR}$ containing Albendazole was able to fight $<90 \%$ of naturally infected Strongyl infections. Efficacy in horses given Oxafax ${ }^{\circledR}$ (containing Oxfendazole) reached $100 \%$ after 28 days of drug administration. The efficacy of Ivo$\operatorname{mec}^{\circledR}$ (Ivermectin) and farbenda was 96\% and $86 \%$, respectively, on day 28 after administration of the drug. When compared with research conducted, the observed efficacy rate was higher where on the 9th day after drug administration had reached the level of $100 \%$. Salas Romero et al. (2018) reported that the use of drugs from the benzimidazole group provided low levels of efficacy in horses of various breeds and races. Worm resistance from the use of benzimidazole in equine cyathostomin cases was reported in at least 14 countries (Peregrine et al., 2014). Meanwhile, Matthews (2014) reports that there is a high level of efficacy against the use of albendazole in natural Strongyl infections in horses and donkeys. The low level of efficacy in several other studies indicates that the prevalence of efficacy of albendazole and other drugs such as Ivermectin and Oxfendazole is due to frequent use, which causes resistance to worms (Islam et al., 2015).
The mechanism of action of albendazole is that it binds to beta-tubulin on the colchicinesensitive side of the cell wall so that it inhibits polymerization and formation of worm tubules. This compound also inhibits spindle formation in the process of cell division, causing obstacles to egg formation and development. Furthermore, albendazole will inhibit glucose uptake by larvae and adult worms resulting in depletion of glycogen stores (Plumb, 2011). However, a longer period time from drug administration without re-administration of anthelmintics can lead to reinfection in horses. Treatment of drug administration for more than 6 weeks without a repeat is likely to lead to worm reinfection in the gastrointestinal tract of horse (Saeed et al., 2008). Imam et al. (2010) stated that giving albendazole both in single and repeated doses showed a reduction in the number of worm eggs by $100 \%$ after 7 days of drug administration. Kuzmina and Kharchenko (2008) also stated that giving albendazole at a dose of $5 \mathrm{mg} / \mathrm{kg}$ body weight showed a significant decrease in the eggs of Strongylus sp. after 10 days of drug administration. Guzel et al. (2014) stated that after a post mortem examination, administration of a single dose of Albendazole produced a low efficacy result of $49.48 \%$ for Habronema sp., $67.09 \%$ for Trichostrongylus axei worms $67.09 \%$, and $67.74 \%$ for worms. Strongyloides westeri. However, Albendazole was found to produce a high level of efficacy in dealing with Parascaris equorum nematodes by $100 \%$, in Strongylus sp. amounted to $98.40 \%$ and Cyathostomum sp. as much as $98.4 \%$.

Table 2. Hematology test results on day-0 ( before treatment) and day-12 (after treatment)

\begin{tabular}{|c|c|c|c|c|c|c|c|c|}
\hline \multirow[b]{2}{*}{ Observation time } & \multirow{2}{*}{$\begin{array}{c}\text { Samples } \\
\text { (n) }\end{array}$} & \multicolumn{7}{|c|}{ Parameter } \\
\hline & & $\begin{array}{c}\text { Erythrocytes } \\
\left(10^{6} / \mu \mathrm{L}\right)\end{array}$ & $\begin{array}{l}\text { Hemoglobin } \\
(\mathrm{g} / \mathrm{dL})\end{array}$ & $\begin{array}{l}\text { PCV } \\
(\%)\end{array}$ & $\begin{array}{c}\text { MCV } \\
\text { (fL) }\end{array}$ & $\begin{array}{c}\mathrm{MCH} \\
(\mathrm{pg}) \\
\end{array}$ & $\begin{array}{c}\mathrm{MCHC} \\
(\%)\end{array}$ & $\begin{array}{l}\text { TPP } \\
(\mathrm{g} / \mathrm{dL})\end{array}$ \\
\hline Normal standart* & & $6,2-10,2$ & $11,4-17,3$ & $31-50$ & $37-53$ & $14-20$ & $36-39$ & $5,8-8,7$ \\
\hline Examination D-0 & 10 & $6,49 \pm 0,61^{\mathrm{a}}$ & $9,55 \pm 1,62^{\mathrm{a}}$ & $\begin{array}{c}35,40 \pm \\
4,88\end{array}$ & $\begin{array}{c}54,82 \pm \\
8,62^{\mathrm{a}}\end{array}$ & $\begin{array}{c}14,84 \pm \\
2,85\end{array}$ & $\begin{array}{c}27,20 \pm \\
4,67^{\mathrm{a}}\end{array}$ & $6,76 \pm 0.60$ \\
\hline Examination D-12 & 10 & $7,93 \pm 0,56^{\mathrm{b}}$ & $11,34 \pm 0,45^{\mathrm{b}}$ & $\begin{array}{c}36,30 \pm \\
2,06\end{array}$ & $\begin{array}{c}45,97 \pm \\
4,31^{\mathrm{b}}\end{array}$ & $\begin{array}{c}14,35 \pm \\
1,08\end{array}$ & $\begin{array}{c}31,35 \pm \\
2,39^{\mathrm{b}}\end{array}$ & $7,08 \pm 0,31$ \\
\hline
\end{tabular}

${ }^{a-b}$ Valures of different superscript on the same column are significantly different $(\mathrm{P}<0,05)$

*Normal standard of hematology refers to Louise (2013)

Explanation $: \mathrm{PCV}=$ Packed Cel Volume, $\mathrm{MCV}=$ Mean Corpuscular Volume, $\mathrm{MCH}=$ Mean Corspuscular Hemoglobin, $\mathrm{MCHC}=$ Mean Corpuscular Hemoglobin Concentration, TPP $=$ Total Protein Plasma 
The administration of albendazole is directly or indirectly related to changes that occur in the blood. Routine hematology results are shown in Table 2.

Hematological examination showed a significant difference in the number of erythrocytes which increased from $6.49 \pm$ $0.61 \mathrm{million} / \mu \mathrm{L}$ to $7.93 \pm 0.56$ million $/ \mu \mathrm{L}(\mathrm{P}$ $<0.05$ ), the total amount of hemoglobin also increased. from $9.55 \pm 1.62 \mathrm{~g} / \mathrm{dL}$ to $11.34 \pm 0.45$ $\mathrm{g} / \mathrm{dL}$. Other measurement results that showed a significant difference were MCV from $54.82 \pm$ $8.62 \mathrm{fL}$, which decreased to $45.97 \pm 4.31 \mathrm{fL}$, and $\mathrm{MCHC}$, which increased from $27.20 \pm 4.67 \%$ to $31.35 \pm 2.39 \%(\mathrm{P}<0.05)$. Louise (2013) states that the normal range of erythrocyte counts in adult horses is $6.2-10.2 \times 106$ cells $/ \mu \mathrm{L}$, normal hemoglobin in adult horses ranges from 11.4 - $17.3 \mathrm{~g} / \mathrm{dL}$. Hemoglobin showed deficiency on examination day 0 , due to high infestation of Strongyl sp. in the horse's digestive tract. However, after treatment with Albendazole administration, it seems that it has increased. Rob et al. (2014) stated that sheep given albendazole increased compared to before drug administration. Amin et al. (2008) stated that the increase in hemoglobin content in the blood is directly proportional to the decreasing number of worms in the cow's body. Axon and Palmer (2008) reported that normal MCV levels in adult horses ranged from $37-53 \mathrm{fL}$, while normal $\mathrm{MCHC}$ values ranged from $36-39 \mathrm{~g} / \mathrm{dL}$. Based on these results, it can be seen that the MCV results on the examination experienced a slight increase on the 0th day but not too significant, the MCHC examination results on the 0th day also looked higher than the normal range. Agina (2017) states that the MCV and MCHC indicators on hematological examination are related to erythrons and can be used to determine whether the animal has anemia, polysetinemia or in normal conditions.

The decrease in MCHC values that occurred on day 0 on examination was closely related to the anemia status that occurred in horses. Amirullah et al. (2018) stated that cows infected with worms will suffer from hypochromic macrocytic anemia or anemia with the formation of erythrocytes larger than normal and decreased hemoglobin content. Egbu et al. (2013) reported that $\mathrm{MCV}$ and $\mathrm{MCHC}$ levels were indicators of anemia in fasciolosis cases. Wiedosari et al. (2006) also stated that adult worms can suck blood 0.2-0.5 ml/day and produce an excretory-secretory product substance that will suppress hematopoietic so that the total production of erythrocytes or hemoglobin decreases. Several studies have reported alterations in blood parameters and blood chemistry as a consequence of $S$. vulgaris infection, including a decrease in $\mathrm{RBC}, \mathrm{PCV}$, total serum proteins and an increase in WBC. Intestinal haemorrhages lead to reduced $\mathrm{RBC}$ survival loss of albumin in intestine leads to increased albumin catabolism (Khan et al, 2015). Islam et al. (2015) reported that cows given treatment with albendazole experienced an increase in hemoglobin counts 28 days after administration. The same thing was reported by Soutello et al. (2009) and Demeler et al. (2009) who stated that there was an increase in the total number of erythrocytes and hemoglobin in animals given albendazole treatment from day 14 to day 28. Barrelet and Rickets (2013) state that anemia caused by parasites is regenerative anemia. In the case of regenerative anemia, the bone marrow is still able to produce erythrocytes in a sustainable manner, but reticulocytes are rarely found in the peripheral blood tissue of horses. The macrocytic condition which shows an increase in the MCHC value at the beginning of the examination, this is due to the large number of young erythrocytes produced by the bone marrow.

Apart from the results of erythrocyte measurements, changes were also seen from the measurement of leukocyte levels as shown in Table 3.

Observation of leukocytes showed no significant differences in leucocytes, segmented neutrophils, and lymphocytes ( $\mathrm{P}>$ $0.05)$, compared with the normal standard, the results showed also showed no difference. Observations on eosinophils and monocytes showed a difference $(\mathrm{P}<0.05)$, the percentage of monocytes also showed a difference with the normal standard where the examination on day 0 showed the number of monocytes that were above the normal limit. The level of eosinophils, which are specific leukocytes against parasitic 
Table 3. Differential examination of leukocytes on day 0 (before treatment) and day 12 (after treatment).

\begin{tabular}{lcccccc}
\hline & & \multicolumn{5}{c}{ Parameter } \\
\cline { 3 - 7 } Observation time & Sample (n) & $\begin{array}{c}\text { Leukosit } \\
\left(10^{3} / \mu \mathrm{L}\right)\end{array}$ & $\begin{array}{c}\text { Neutrofil } \\
\text { Segmented } \\
(\%)\end{array}$ & $\begin{array}{c}\text { Eusinofil } \\
(\%)\end{array}$ & $\begin{array}{c}\text { Limfosit } \\
(\%)\end{array}$ & $\begin{array}{c}\text { Monosit } \\
(\%)\end{array}$ \\
\hline Normal standard* & & $4,9-10,3$ & $28,0-82,8$ & $0-8,7$ & $19,8-58,9$ & $1,4-10,5$ \\
Examination D-0 & 10 & $8,14 \pm 2,13$ & $45,20 \pm 18,28$ & $2,30 \pm 2,63^{\mathrm{a}}$ & $38,50 \pm 15,06$ & $14,20 \pm 6,65^{\mathrm{a}}$ \\
Examination D-12 & 10 & $7,50 \pm 0,59$ & $57,70 \pm 4,14$ & $5,50 \pm 1,08^{\mathrm{b}}$ & $27,50 \pm 4,17$ & $9,30 \pm 1,16^{\mathrm{b}}$ \\
\hline
\end{tabular}

${ }^{\mathrm{a}-\mathrm{b}}$ Valures of different superscript on the same column are significantly different $(\mathrm{P}<0,05)$

* Normal standard of hematology refers to Louise (2013)

pathogens, did not show a percentage that exceeded the standard, but it was seen that on the $12^{\text {th }}$ day of the examination, euosnophils had increased compared to the examination on day 0. According to Amirullah et al. (2018) several factors that determine the ups and downs of eusinophil levels include the number of worms in the animal's body and the presence or absence of secondary infections that occur after treatment. Wiedosari et al. (2006) stated that after reinfection in animals, the immune process occurs at least 5 weeks after infection occurs, and the level of antibodies formed is also higher than that of the first infection. Zhang et al. (2006) stated in cases of infection from Fasciola sp. which continues will cause eosinophilia at week 3 to week 13 post-primary infection, after which the eosinophil content will decrease.

The high number of leukocytes found on the $0^{\text {th }}$ day of examination can be caused by the high number of phagocytosis that occurs during inflammation, this can be caused by tissue necrosis. Besides, monocytosis is also related to the recovery phase after a viral infection (Barrelet and Rickets, 2013). Examination of total leukocytes indicated a decrease in the number of blood counts from day 0 of blood count to day 12 of blood count, although it did not look significant. Amin et al. (2008) stated that the results of treatment with albendazole resulted in a decrease in the total number of leukocytes compared to before being given the drug. Khalid et al. (2005) also stated that the total leukocytes in sheep given albendazole also decreased significantly compared to pre-treatment.

\section{Conclusion}

The results showed that giving albendazole to 10 guava horses gave a significant level of efficacy to the number of Strongyl sp. Worm eggs. in every gram of feces. Examination with Mc Master showed an efficacy rate of $100 \%$ on the 9th day after administration of albendazole took place. Hematological examination showed that the horse had symptoms of hyperchromic macrocytic anemia when albendazole treatment had not been performed, this was due to the presence of Strongyl sp. in high infection rates. Observation of the hematological parameters also showed some significant differences in the presence of albendazole administration compared to before treatment.

\section{Acknowledgement}

This research was funded by the BPPTNBH FKH UGM grant from the Ministry of Research, Technology and Higher Education of the Republic of Indonesia. We also thank to the head of the Department of Internal Medicine, Faculty of Veterinary Medicine, UGM for their support in conducting the research

\section{References}

Agina, O.A. (2017). Haematology and clinical biochemistry findings associated with equine diseases : A Review. Not.Sci.Biol 9 (1) : 1-21.

Amin, M.R., Mostofa, M., Awal, M.A., and Sharmin, M.L. (2008). Comparative efficacy of barbados lilac, pineapple, and Benazol ${ }^{\circledR}$ againts gastrointestinal nematodes in cattle. Progress. Agric. 19(1) : 51-59.

Amirullah, Dradjat, A.S, Sriasih, M., Maskur, Depamede, S.N., Kisworo, D., dan Kurniasih. (2018). Pengaruh Fasciolosis pada Sapi Bali Berdasarkan Pemeriksaan 
Darah, Serum Glutamic Pyruvic Transaminase (SGPT) dan Alkaline Phosphatase (ALP). JSV 36 (2) : 247-253.

Apriliawati, E., Mufasirin, Wurlina, Hastutiek, P., Suwanti, L.T., dan Tehupuring, B.C. (2019). Prevalensi dan Tingkat Infeksi Nematoda pada Saluran Gastrointestinal Kuda (Equus caballus) di Bangkalan Madura. Journal of Parasite Science 3(2) : 83-88.

Axon, J.E and Palmert, J.E. (2008). Clinical pathology of the Foal. Vet Clin Equine 24 : 357 -385.

Barrelet, A and Rickets, S. (2013). Haematology and blood biochemistry in the horse : a guide to interpretation. Retrieved September 20, 2020, from https :// inpractice.bmj.com.

Cernea, L.C., Cernea, M., Ognean, L., Nastasa, V., Raileanu, S., Mares, M., Chereji, A. and Carvalho, L.M. (2007). The efficacy of tetrahydropyrimidines and benzimidazoles combination in equine Strongylidosis. Rev. Sc. Parasitol., Vol. 3 (1) : 28-35.

Demeler J, Van Zeveren, A.M, Kleinschmidt, N, Vercruysse J, Höglund J, Koopmann R, Cabaret J, Claerebout E, Areskog M and von Samson- Himmelstjerna G. (2009). Monitoring the efficacy of ivermectin and albendazole against gastro intestinal nematodes of cattle in Northern Europe. Veterinary Parasitology 160(1) : 109-15.

Gokbulut, C., F. Akar, Q. A. and McKellar. (2005). Plasma disposition and faecal excretion of oxfendazole, fenbendazole and albendazole following oral administration to donkeys. Vet. J. 172, 166-172.

Guzel, S., Tanriverdi, M., and Senlik, B. (2014). Selected biochemical parameters in Strongyle infections of horses and its relationship with the parasite burden. Bulgarian Journal of Agricultural Science, 20 (5) :1233-1236.

Egbu, M.I. Florence., O.P. Ubachukwu, C.I. Okoye. (2013). Haematological Changes
Due to Bovine Fascioliasis. Afr. J. Biotechnol., 12 (15):1828-1835.

Howell, S. B., Burke, J. M. and Miller, J. E. (2008). Prevalence of Anthelmintic Resistance on Sheep and Goat Farms in The Southeastern United States. Journal of The American Veterinary Medical Association 233 (12): 1913-1919.

Islam, M., Islam, S., Holader, M, R. and Lucky, N.S. (2015). Comparative efficacy of Albendazole, Fenbendazole and Levamisole against gastrointestinal nematodiasis in cattle of Bangladesh. International Journal of Biological Research 3(1) : 23-35.

Imam, S.M.A., Seri, H.I., Hassan, T., Tigani, T.A., Zolain, H.B. and Abakar, A.D. (2010). Therapeutic efficacy evaluation of anthelmintics activity of albendazole and ivermectin drench formulations in donkeys in Darfur, Sudan. Vet.arhiv 80(5): 585-595.

Khalid, S. M. A., Amin, M. R., Mostofa, M., Choudhury, M. E. and Uddin, B. (2005). Effects of indigenous medicinal plants (neem and pineapple) against Gastrointestinal nematodiasis in sheep. Internat. J. Pharma., 1(2): 185-189.

Khan, M.A., Roohi, N. and Rana, M.A.A. (2015). Strongylosis in equine: A Review. J. Anim. Plant Sci. 25 (1): 1-9.

Koesdarto, S., S. Subekti., S.M. Sosiawati., H. Puspitawati dan Kusnoto. (2007). Buku Ajar Ilmu Penyakit Nematoda Veteriner. Departemen Pendidikan Nasional Fakultas Kedokteran Hewan Universitas Airlangga. Surabaya. Hal: 1-5

Kristiyani, F., Aini, N., dan Wiyanati, A.D. (2019). Evaluasi pengobatan Trematodiasis menggunakan Albendazol pada sapi di Kecamatan Pakem, Sleman, Daerah Istimewa Yogyakarta. JSV. 37(1) : 104-11

Kuzmina, T. A., and Kharcenko, V.O (2008): Anthelmintic resistance in cyathostomins of brood horses in Ukraine and influence of anthelmintic treatments on Strongylid 
community structure. Vet. Parasitol. 154, 277-288.

Louise, L.S. (2013). Practical Guide to Equine Colic. $1^{\text {th }}$ ed. John Willey \& Sons, Inc Published, Iowa.

Love, S. (2003). Treatment and prevention of intestinal parasite associated disease. Vet. Clin. Equine. 19: 791 - 806.

Matthews, J.B. (2014). Anthelmintic resistance in equine nematodes. Vet. Parasitol 4 : 310-315.

Nofyan, E., M. Kamal dan I. Rosdiana. (2010). Identitas jenis telur cacing parasit usus pada ternak sapi (Bos sp.) dan kerbau (Bubalus sp.) di rumah potong hewan Palembang. Jurnal Penelitian Sains. (D) 10:06-11.

Peregrine, A.S., Molento, M.B., Kaplan, R.M., and Nielsen, M.K.. (2014). Anthelmintic resistance in important parasites of horses: does it really matter?. Vet. Parasitol. 201, $1-8$.

Plumb, D. (2011). Albendazole. Plumb's Veterinary Drug Handbook. 7th ed. Wisconsin; Ames, Iowa. Willey. 19-21

Pradana, F.H.A.(2012). Tingkat Kejadian Helminthiasis Gastrointestinal pada Kuda Pacu di PT. KTS Pohsarang, Kediri. [Tesis] Fakultas Kedokteran Hewan, Universitas Airlangga. Surab

Ratnawati, E.W. (2004). Kejadian Infeksi Cacing Parasit Saluran Pencernaan pada Kuda Delman di Kota Bogor. [Skripsi] Fakultas Kedokteran Hewan Institut Pertanian Bogor: Bogor.

Rob, S., Mostofa, M., Awal, M. A., Shahiduzzaman, M. and Sardar, S. A. (2014). Comparative efficacy of albendazole $\left(\right.$ Endokil $\left.^{\circledR}\right)$ and neem (Azadirachta indica) leaves extract against haemonchosis in sheep. Prog. Agril., 15(2): 33-39.
Saeed, K., Qadir, Z., Khan, S.A., Ashraf, K. and Nazir, S. (2008). Evaluation of some broad spectrum antiparasitic drugs against natural Strongyl infections in horses. $J$. Anim. Pl. Sci. 18(2-3): 64-66.

Salas-Romero, J., Gomez-Cabrera, K.A., Salas, J.E., Vazquez, R., Arenal, A., and Nielsen, M.K. (2018). First report of anthelmintic resistance of equine cyathostomins in Cuba. Veterinary Parasitology: Regional Studies and Reports 13 :220-223

Siregar, D.O. 2016. Prevalensi Cacing Nematoda dan Derajat Infeksi Nematodiasis Kuda di Kota Batu. [Tesis] Fakultas Kedokteran Hewan, Universitas Airlangga. Surabaya.

Soutello RG, Seno, M.C dan Amarante, A.F. (2009) Anthelmintic resistance in cattle nematodes in northwestern São Paulo State, Brazil. Veterinary Parasitology 148(3-4), 360-364.

Subekti,S.,S. Mumpuni, S. Soedarto, H. Puspitawati dan Kusnoto. (2010). Buku Ajar Parasitologi Veteriner. Fakultas Kedokteran Hewan Universitas Airlangga. Surabaya.

Wiedosari. E., H. Hayakawa, B. Copeman. 2006. Host differences in response to trickle infection with Fasciola gigantica in buffalo, Ongole and Bali calves. Trop. Anim. Health Prod. 38:43-53.

Yuriadi. (2007). Data Hematologi Kuda yang dipelihara Di Daerah DIY dan Jawa Tengah. Seminar Nasional dan Kongres PDHI, Jakarta.

Zhang,W.Y., M. Moreau,B.Z. Yang, Z. Q.Li, J.C. C. Hope, J. Howard, and Y. W.Huang. (2006). Humoral And Cellular Immune Responses To Fasciola Gigantica Experimental Infection In Buffaloes. Research In Vet. Sc. 80: 299-307. 